\title{
FINANCIAL MARKETS IN DECEMBER 2013
}

\author{
N.Andrievsky, E.Khudko
}

The MICEX Index growth during the last month in 2013 has been governed basically by steady gaining Norilsky Nickel's stocks in response to information about the enterprise's successful performance. In general, however, it is Sberbank's preferred stock that remains most profitable investment at year end. The MICEX stock market capitalization amounted to Rb 25,02 trillion (38.45\% of GDP) by December 20, 2013. Positive dynamics of the key indicators such as market volume and market index has died out in the corporate bond market. At the same time, issuers and investors keep showing a high level of activity. The situation with issuers' discharge of their obligations to bondholders remain stable in December 2013.

\section{Dynamics of Russian stock market basic structural indices}

The MICEX index gained $1 \%$ in the period of December 2, 2013 thru December 23, 2013. The monthly lowest value was reached at 1429,25 points over three trading days since the beginning of the month when the index lost 3\%.It was the shares of Norilsky Nickel, VTB and Rosneft that were basically responsible for the gain in the MICEX index in December. The Norilsky Nickel stock demonstrated its highest value since the beginning of the month, having reached $8.4 \%$ by December 19,2013 . The the price of the stock rose mainly in response to the upcoming annual general meeting of shareholders at which the Board of Directors was expected to pay dividends accounting for $4 \%$ of the stock value as of the beginning of the month and 50\% EBITDA at the end of three quarters in 2013. The VTB stock has been growing since December 16, 2013 in response to the news about a 2.4-fold increase in bank's net profit over 11 months vs. 2012. Sberbank preferred shares lost more against other stocks in December 2013, having fallen $6 \%$ in the period between the beginning of the month and December 17, 2013.

Nonetheless, annual results remained positive for the Sberbank stock despite a negative price dynamics in December 2013: the preferred shares gained 21.2\% in the period of December 24, 2012 thru December 23, 2013 during the year while its common shares rose $10.8 \%$ during the same period. It should be noted that Norilsky Nickel and VTB lost $4.7 \%$ and $9.4 \%$ respectively during the same period.

The sector indices saw growth at the end of the $12^{\text {th }}$ month of 2013 , except the consumer sector companies index which lost $0.5 \%$ in the period between the beginning of the month and December 23, 2013. The energy sector index was leading in growth, its growth rate increased $9.5 \%$ in the period between the beginning of the month and December 23, 2013. The

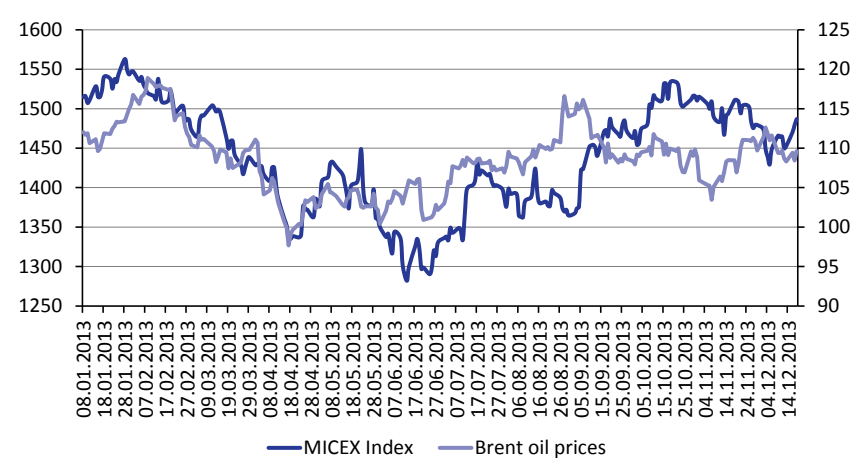

Source: RBK Quote.

Fig. 1. Dynamics of the MICEX index and futures Brent oil prices in the period of 08 January 8, 2013 thru December 18, 2013

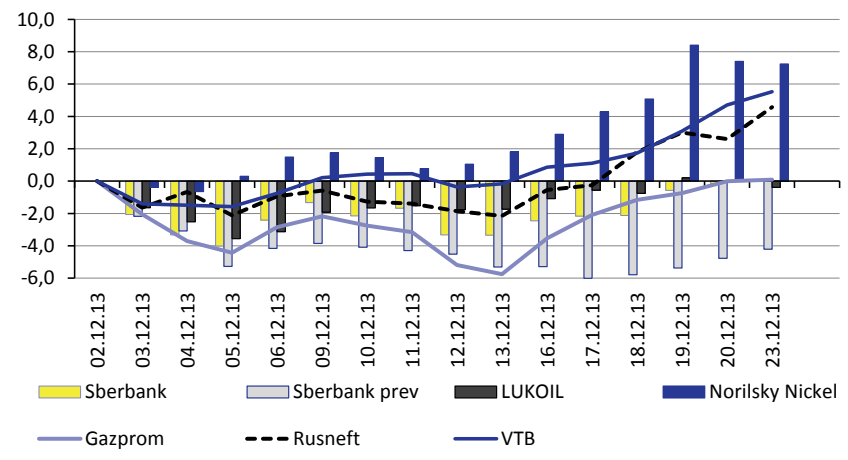

Source: RBK Quote, author's estimates.

Fig. 2. Blue chips growth rates in the Moscow Stock Exchange in August 2013 (over a period since the beginning of the month)

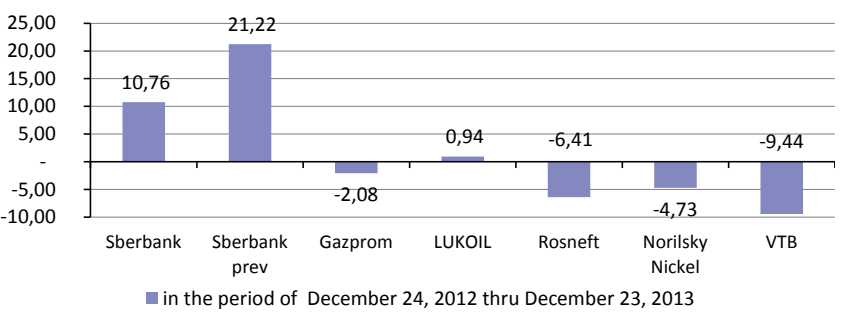

Source: RBK Quote, author's estimates.

Fig. 3. Blue chips growth rates in the Moscow Stock Exchange in the period of December 24, 2012 thru December 23, 2013 
shares of Rosseti, MOESK, and OGK-2 were the key growth drivers for the index.

According to the Emerging Portfolio Fund Research (EPFR), Russian market-oriented foundations saw a capital outflow of $\$ 70 \mathrm{~m}$ in the period of November 28, 2013 thru December 12, 2013. Russia's stock market (MICEX) capitalization totaled $\mathrm{Rb} 25$ trillion (38.05\% of GDP) as of December 20, 2013, having shown a decline of $\mathrm{Rb} 880,6 \mathrm{bn}$ (3.6\%) against the value observed as of December 2, 2013. The share of the mineral extraction sector remained at the level of capitalization, $49 \%$. The manufacturing sector and financial sector accounted for $12.8 \%$ and $14.6 \%$ respectively of capitalization.

\section{Corporate bond market}

The Russian domestic corporate bond market volume (measured by the par value of outstanding securities denominated in the national currency, including those issued by non-residents) saw a significant slowdown in growth rates in December 2013. By the end of December 2013 this indicator reached Rb 5069,4bn, as little as $0.8 \%$ above the value observed at the end of November $2013^{1}$. It should be noted that growth in the market capacity was associated with the replacement of redeemed bond issues with new ones of a bigger volume, because the quantity of bond issues remained the same and the number of issuers in the bond segment (355 issuers against 354 companies as of the previous month end) even declined from year to month (1034 corporate bond issues registered in the national currency against 1039 at the previous month end). In addition, there are outstanding 12 USD-denominated bond issues of Russian issuers (a total of more than $\$ 1.8 \mathrm{bn})$, and a JPY-denominated bond issue.

Investment activity in the secondary corporate bond market in December 2013 increased again after insignificant decline in the previous month but failed to reach the trading level of the last three quarters. For instance, in the period of November 26, 2013 thru December 19, 2013, total volume of transactions in the Moscow Stock Market amounted to Rb $160,5 \mathrm{bn}$ (trading volume in the period of October 24, 2013 thru 25 November 2013 amounted to Rb 148,8bn), whereas the number of transactions declined to 23,500 in the period under review $(29,500$ transactions in the previous period) $)^{2}$. Such a trading dynamics shows that major transactions with securities were dominating. Furthermore, it should be noted that trading volumes were determined mostly by domestic investors, because international investors have been less active in the bond markets over the last few weeks. The Russia corporate bond market index IFX-Cbonds

1 According to Rusbonds information agency.

2 According to Finam Investment Company.

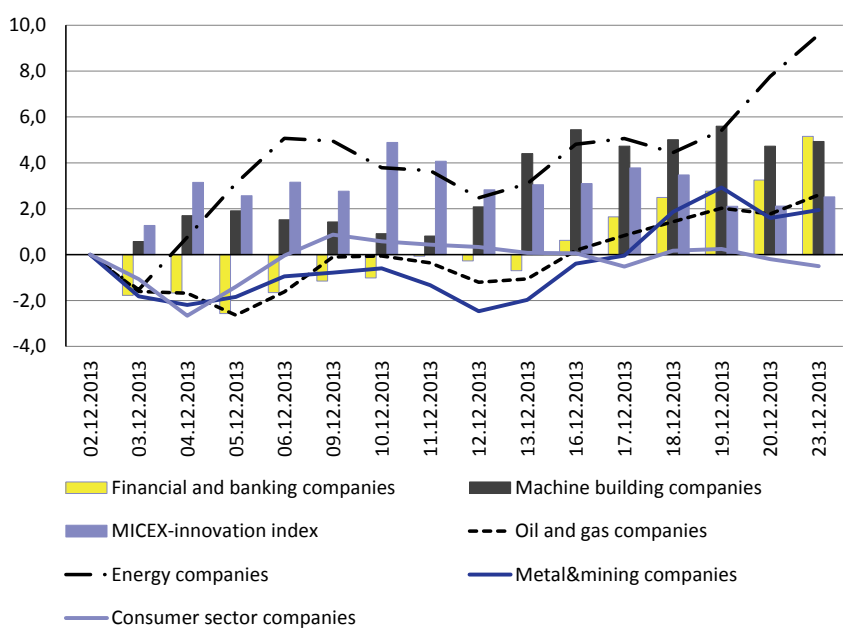

Source: RBK Quote, author's estimates.

Fig. 4. Growth rates in various sector stock indices at the Moscow Stock Exchange

(over a period since the beginning of the month)

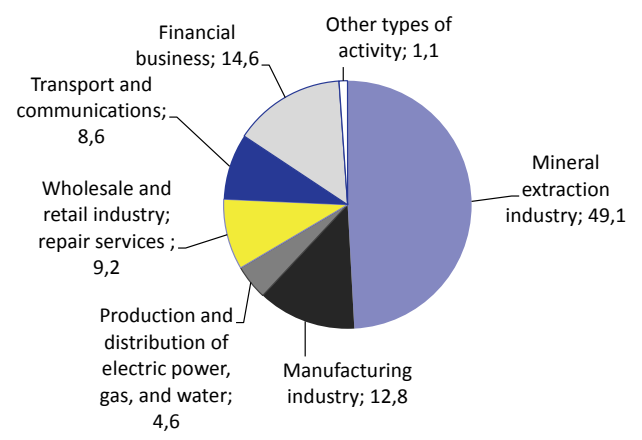

Source: The Moscow Stock Exchange's official website, authors' estimates.

Fig. 5. Stock market capitalization structure by type of economic activity

remained unchanged in December 2013 after a longlasting growth. By the end of December 2013 it gained 0.3 points (or $0.08 \%$ ) as compared to the corresponding value observed at the end of the previous month. Unlikewise, after a few months of stabilization the corporate bond average weighted yield skyrocketed by $8.64 \%$ by the end of December 2013 against $8.05 \%$ at the end of November 2013 (Fig. 6), having reached its highest in 2013, with most of the growth being observed in the second half of December $2013^{3}$.

The corporate bond yield rose in response to mounting tensions in the banking sector, leading unavoidably to a credibility crisis, and downgraded credit rankings and/or forecasts for major issuers, namely CJSC Globex Bank, OJSC OPT Bank, OJSC Sovcomflot, CJSC TransTeleCom. Furthermore, the yield was also affected by inflation which is expected to exceed a forecast ceiling of 6\% at the 2013 year-end. Neither do macroeconomic

3 According to Cbonds Information Agency. 
statistics seem to be optimistic for investors (in particular, a decline in industrial output).

The corporate bond portfolio duration value skyrocketed as much as the yield did. The duration was 737 days as of the end of December 2013, which is 74 days longer than the value observed as of the end of the previous month. The higher value of duration due to skyrocketed interest rates reflects significant growth in maturity of flow of payments on bonds, and, therefore, of outstanding bond issues in the corporate segment.

The most liquid segment of the corporate bond market saw a strong yield of bond issues. Like in the previous months, it was financial corporate issuers that experienced most significant changes in their bond yield (more than 1 p.p.). The yield of bond issues of high-tech companies was growing in December 2013 (although this segment saw a two-month downtrend in the yield of its bond issues). The bond issues in the energy sector saw the same uptrend in the yield. The industrial sector experienced mixed trends in December 2013 against the previous few months. In particular, the yield of certain Gazprom bond issues decreased at month end ${ }^{1}$.

In spite of the market slump in December 2013, Russian bond issuers were less active to register new bond issues as compared to the record-high activity observed in November 2013. Nonetheless, their activity remained at a high level. For instance, For instance, 15 issuers placed 38 bond issues denominated in rubles at an aggregate par value of $\mathrm{Rb} 164,2 \mathrm{bn}$ in the period of November 26, 2013 thru December 19, 2013 (to compare, 72 bond issues denominated in rubles at $\mathrm{Rb} 123,3 \mathrm{bn}$ were registered in the period of October 24, 2013 thru November 25, 2013, and at Rb 123,3bn in October 2013). Major issues were registered by CJSC Credit Europe Bank, ZAO VTB 24-2 mortgage agent, LLC TransFin-M, LLC OBK Finance ${ }^{2}$. Listed bonds accounted for more than a half of the registered issues. Moreover, it should be noted that lots of long maturity mortgage securities were registered in December 2013. This might increase considerably the average duration in the market in case of successful bond placement and stabilization of interest rates in the market shortly.

Investment activity in the primary market increased significantly in December 2013, having reached the highest value of the year, despite general pessimism of the market players. For instance, 15 issuers placed 24 bond issues at an aggregate par value of $\mathrm{Rb} 218,2 \mathrm{bn}$ in the period of November 26, 2013 thru December 19, 2013 (to compare, 28 series of bonds at $\mathrm{Rb} 116,4 \mathrm{bn}$ were placed in the period of October 24, 2013 thru November 25, 2013) (Fig. 7). Major bond issues were placed by OJSC Russian Rail-

1 According to Finam Investment Company.

2 According to Rusbonds information agency.

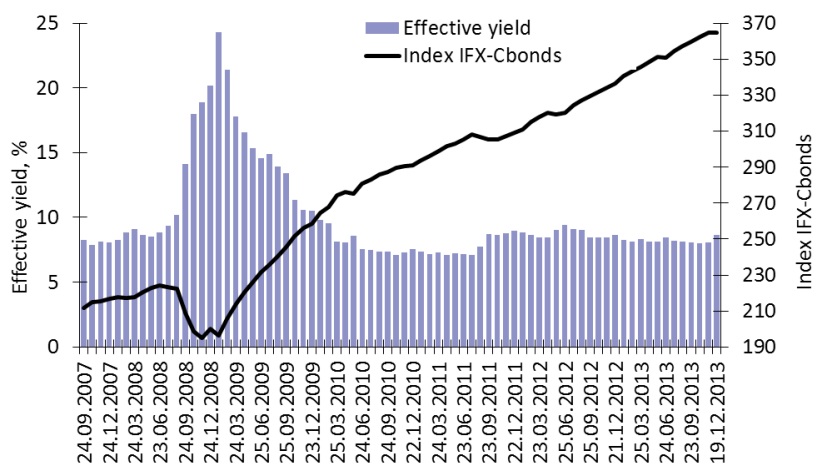

Source: According to Cbonds Information Agency.

Fig. 6. Dynamics of the Russian corporate bond market index and average weighted yield

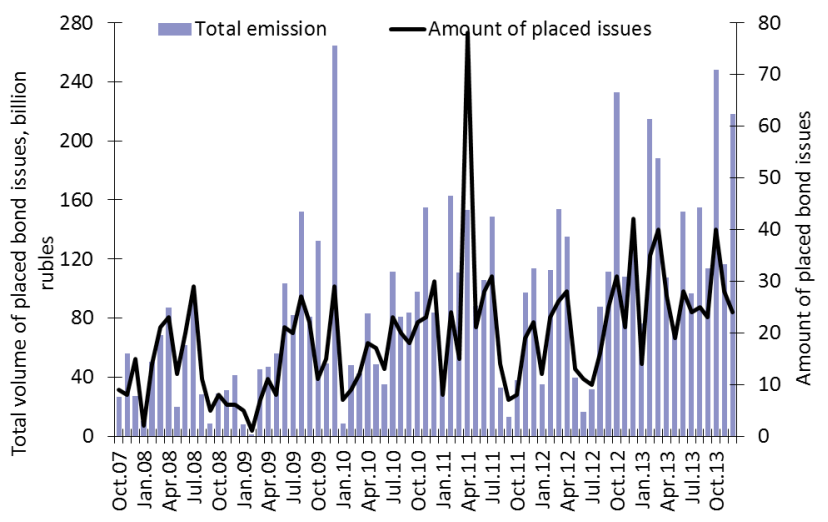

Source: According to Rusbonds information agency.

Fig. 7. Dynamics of initial public offerings of corporate bonds denominated in the national currency

void by the Bank of Russia Financial Markets Service for non-placement of a single bond (no bond issues were declared void for the same reason in the previous month) 4 . In this case, however, it refers to bonds issues (including debut bond issues) offered by basically middle-range issuers.

In the period of November 26, 2013 thru December 19, 2013, all of the 23 issuers redeemed their bond issuers at an aggregate value of $\mathrm{Rb} 68,2 \mathrm{bn}$ in the due date (to compare, all of the issuers discharged their obligations and no technical default was announced in the preceding period). This is a positive factor in the market. Four corporate bond issues at a total of $\mathrm{Rb} 3,0 \mathrm{bn}^{5}$ are to be redeemed In January 2014.

Furthermore, like in the previous period, no real default(s) on coupon yield payment and early redemption(s) of securities on put date were reported in the market in the period of November 26, 2013 thru December $19,2013^{6}$.

\footnotetext{
3 According to Rusbonds information agency. 4 According to the Bank of Russia Financial Markets Service. According to Rusbonds company. According to Rusbonds company.
} 